Historic, Archive Document

Do not assume content reflects current scientific knowledge, policies, or practices. 

$\frac{1}{\pi} 8118 \pi 879$

Fg 84 Pro

cor. 2
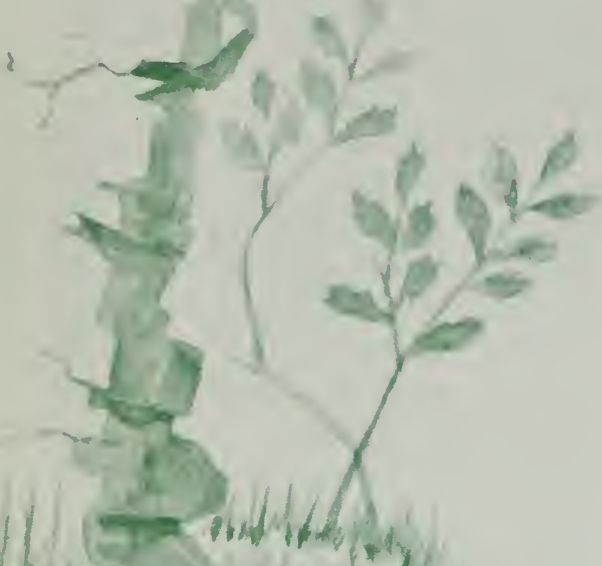

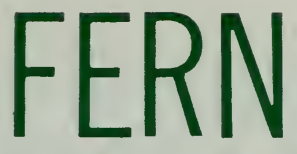

VALLEY

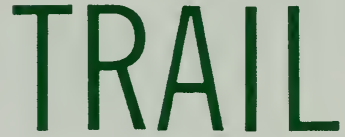

THE

NATIONAL

ARBORETUM

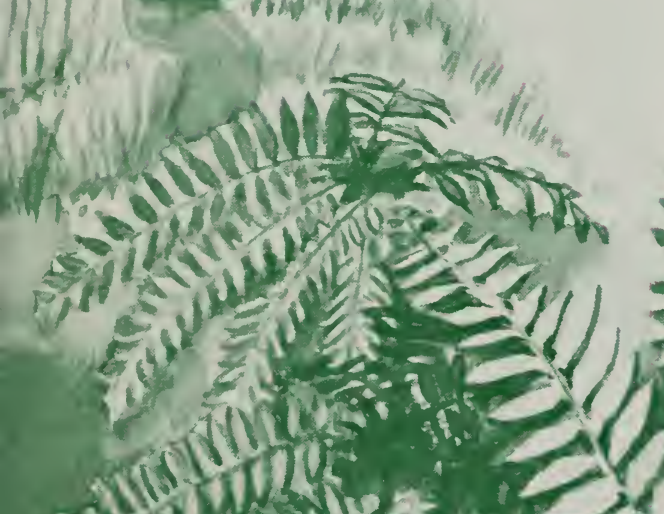

Nofín:

Sin.

Nivilu

2in

mo
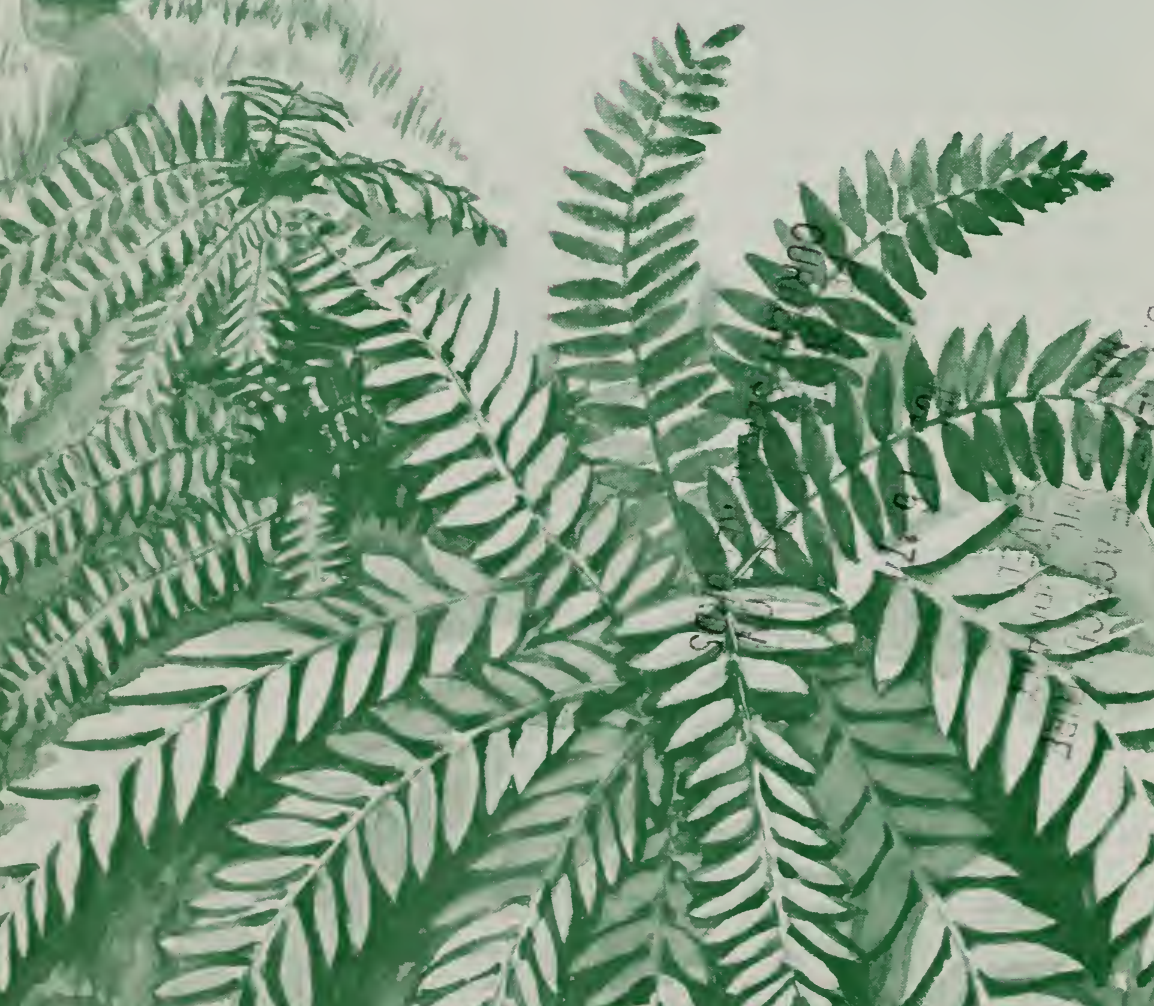

on $y^{2}$

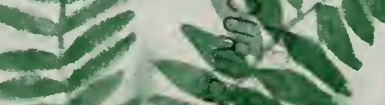

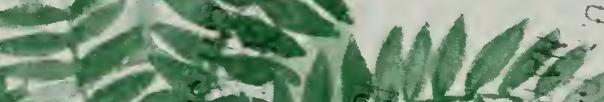

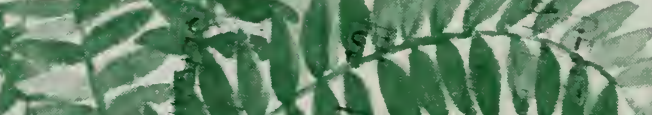

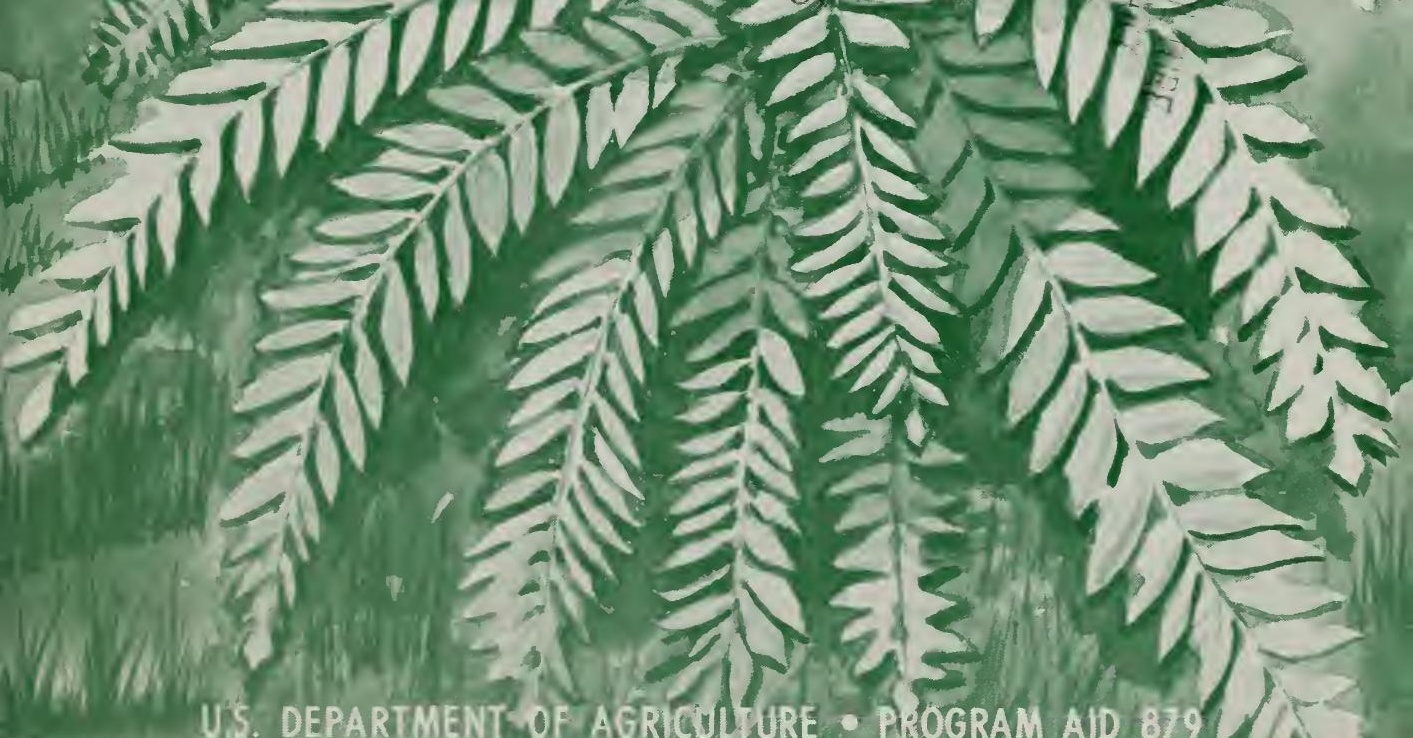

US. DEPARTMENT OF AGRIULSURE PROGRAM AID : 9 UJ 


\section{THE NATIONAL ARBORETUM}

$\mathbf{F}$ ern Valley is a natural wooded area planted with ferns, wildflowers, and native trees and shrubs. It is a joint nature-education project of the U.S. National Arboretum and the National Capital Area Federation of Garden Clubs.

Planting was begun in the Valley in the spring of 1959 with a donation of 1,000 ferns. Since that time thousands of native plants have been planted by volunteer workers, all members of local garden clubs.

A map of the trail through Fern Valley is on p. 8. Numbers on the map and the numbered description in this booklet correspond to numbered stakes along the trail. In addition, many of the trees, ferns, wildflowers, and shrubs are labeled.

In Fern Valley you may see most of the ferns and many of the shrubs and wildflowers native to the eastern United States. Additions are continually being made to the plantings.

\section{Plan of the Valley}

As you enter the Valley notice the group of evergreen trees in the area to the left. Plants, like people, live together in groups liking the same type of environment. These plant groupings are called plant associations. In this upper part of the Valley are plant associations natural to the northeastern part of the United States. Hemlock, pine, and spruce have been planted here among the deciduous trees, with clubmosses, wintergreen, partridgeberry, and a variety of ferns on the forest floor.
In midvalley are found plants conmon to deciduous woodlands of the Piedmont area. In the lower part of the Valley have been placed plants that are found in more southern areas. There you will see an association of rhododendrons, azaleas, sandmyrtle, wandflower, Oconee bells, and blue berry such as is found on some of the mountains in North Carolina.

Throughout the Valley you will see, with their characteristic plants, a variety of plant habitats-moist and dry slopes, a limestone area, a talus slope, streain and pond edges, a forest edge, a swamp.

\section{Trail Markers}

1. The large tree beside the path is WHITE OAK (Quercus alba), the most common oak of the eastern United States. Its wood is of great commercial value; it is used for many kinds of construction.

2. The CHRISTMAS FERN (Polystichum acrostichoides/is found throughout the eastern United States. Its evergreen fronds are conspicuous in winter on hillsides. It is easily recognized by its eared leaflets.

3. This little evergreen vine, PARTRIDGEBERRY (Mitchella repens), has at least 20 common names, but just one scientific name. To avoid confusion it is best to use the scientific names of plants.

4. The large tree with smooth. gray bark, the AMERICAN BEECH /Fagus grandifolia), is found in every State cast of the Mississippi. Its fruit, a tiny bur 
containing two nuts, is a favorite food of many birds and animals.

5. The CINNAMON FERN /Osmunda cinnamomea) grows best in swamps, on stream banks, and in other moist areas. The brownish wool on the fiddleheads in spring is used as nest material by many small birds.

TALUS SLOPE.-To the right of the path a rocky slope or talus slope has been constructed to provide a habitat for the marginal shieldfern (Dryopteris marginalis), the spinulose woodfern (D. intermedia), and other plants, including the hepaticas and trilliums, that thrive in the shade and loose humus of rock crevices.

6. Notice here the SOLOMONS SEAL (Polygonatum canaliculatum) with flowers and fruit hanging beneath each leaf, and the FALSE SOLOMONS SEAL (Smilacina racemosa), with flowers and fruit in a cluster at the end of the stem Because the leaves are similar, people sometimes confuse these two plants. BENCH.-As you stop to rest at the

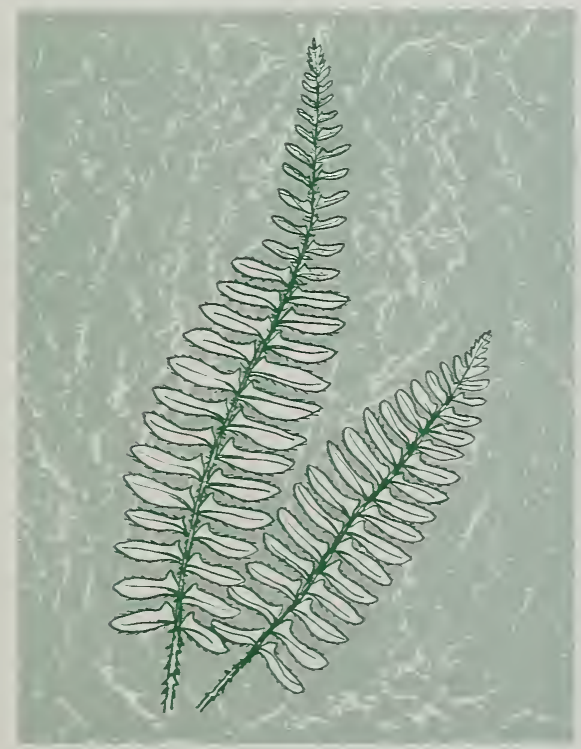

CHRISTMAS FERN

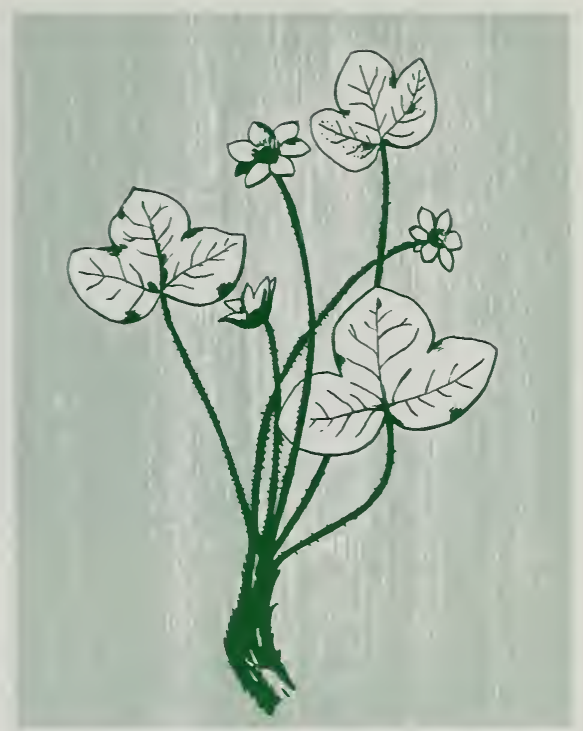

ROUNDLOBED HEPATICA

bench look around you at the smooth, gray trunks of the many beech trees. Ecologists consider the beech a climas tree, meaning that it is a tree typical of a plant community that is mature or stable, rather than of one in a state of change. Notice the other trees with which it is associated-the tuliptrees and oaks and, on the sunnier and drier side of the Valley, the hickories. Look for the wildflowers that bloom here on the floor of the deciduous forest before the trees leaf out to shade them--the bluebells, springbeauty, bloodroot, toothwort, Dutchmans-breeches, merrybells, Solomons seal, and many others.

7. Across the stream is a large TULIP TREE (Liriodendron tulipifera). The tulip tree is America's tallest native deciduous tree, sometimes growing nearly 200 feet tall. The tree, which is a relative of the magnolia, gets its name from its yellow, tuliplike flower.

8. This evergreen fern, the ROCK POLYPODY (Polypodium virginianum) is also called rockcap fern. It grows 


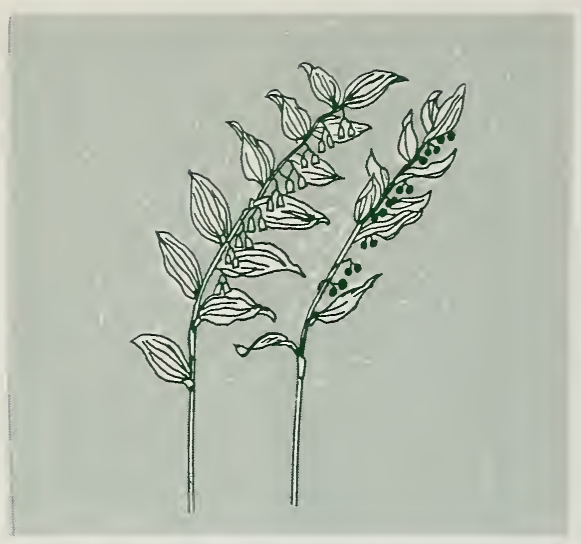

\section{SOLOMONS SEAL}

best on rocks, where it forms large mats. 9. Here a CHESTNUT TREE (Castanea dentata) continues to send up shortlived sprouts. The chestnut, once one of our largest and most useful forest trees, grew throughout the eastern United States. Then it was destroyed by the chestnut blight, which was first observed in New York in 1904. Now, though sprouts continue to grow from the roots of many old trees, they are soon killed by the blight.

10. The delicate plumy fronds of the NEW YORK FERN (Thelypteris noveboracensis) brighten shaded spots in moist woods. It is sometimes called the tapering fern; it can be recognized by its fronds, which taper at both ends. 11. The MOUNTAIN LAUREL/Kalmia latifolia) is a common evergreen shrub in acid woods. In more open locations it blooms profusely and is much used for landscaping.

12. The TUPELO, or black or sour gum (Nyssa sylvatica), of ten grows on mountain slopes, along the borders of swainps, and in wet, poorly drained soil. In early fall its leaves turn a brilliant red. 13. Under the foliage of taller trees, the forest canopy, grow smaller trees and shrubs that require less sunlight. They form an understory. A part of this understory is ARROWWOOD (Viburnum dentatum). It is one of our many species of viburnums, all handsome flowering shrubs.

14. The path to the right leads through a planting of native rhododendron (Rhododendron catawbiense and $R$. carolinianum), southern azaleas, sandmyrtle, and pieris, with an underplanting of wandflower, Oconee bells, blue berry, and wintergreen. This planting, begun in 1965 , resembles a plant association that might be found in the southern Appalachians.

15. The FRANKLIN TREE (Franklinia alatamaha) was discovered in 1765 by the American botanist John Bartram. He found it growing near the Altamaha River, in Georgia. It has not been found in the wild since 1790 and is now known only in cultivation.

16. The RED MAPLE (Acer rubrum is common in damp locations and along river banks. Its blossoms and young winged seeds are bright red in early spring.

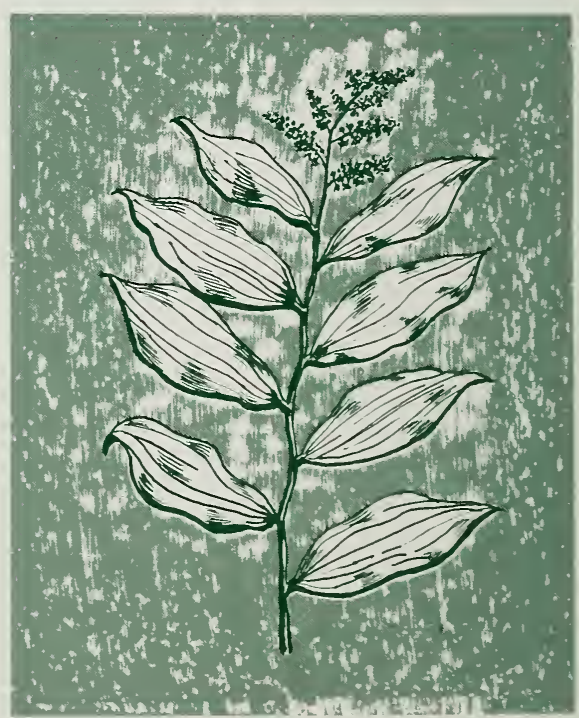

FALSE SOLOMONS SEAL 


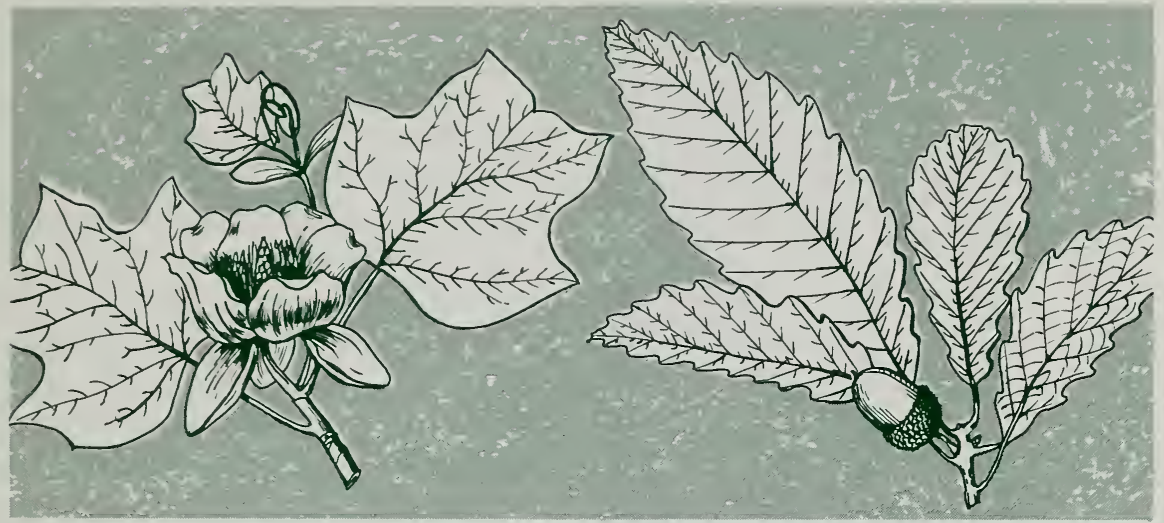

TULIPTREE (LEFT), CHESTNUT OAK

\section{The SPICE BUSH (Lindera benzoin)} is found in moist locations throughout our area. Its yellow blossoms appear before the leaves. Its red fruit is relished by birds.

18. The SWEET BAY (Magnolia virginiana)grows in swamps and wet woods from Massachusetts to Florida. Its fragrant white blossoms appear from May to July. Notice its bright green twigs and its leaves, which are lighter underneath.

19. The plant with the shiny round leaves is the WANDFLOWER (Galax aphylla). Under the laurel at the foot of the bank is the OCONEE BELLS (Shortia galacifolia). Both are evergreen plants native to our southern mountains. The wandflower has many blossoms on a stalk, while each flower of Oconee bells is on a single stem. Oconee bells is well known as one of America's "lost plants." Until its rediscovery in 1878 , it was known only as a specimen in a French herbarium. Asa Gray, one of America's noted botanists, searched for 40 years for Oconee bells and was delighted when an herb collector rediscovered it growing in the southern Appalachians.

20. The plants behind the marker are
ROYAL FERNS (Osmunda regalis). These ferns are common in swampy locations, and grow even in shallow water. Also growing in the swamp are cinnamon ferns and chain ferns, the possumhaw, button bush, sweet bay, bald cypress, and other plants characteristic of the southeastern evergreen forests of the Coastal Plain. Notice how different this kind of plant community is from that of the mature deciduous forest (near stake 6) where beech is the climax tree.

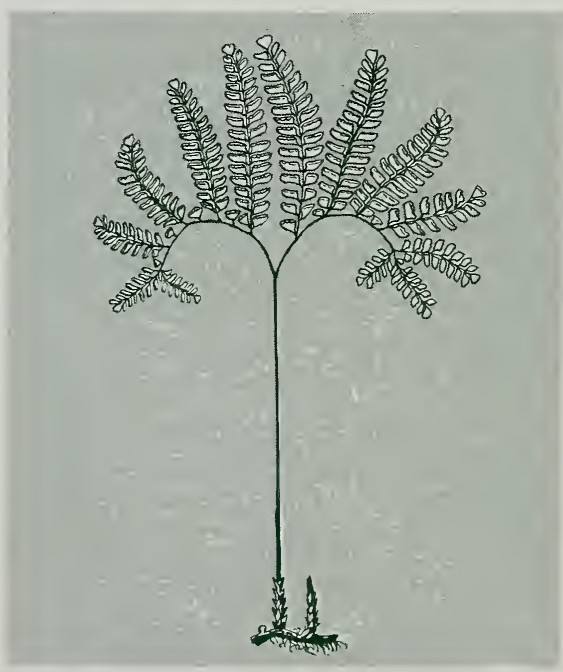

NORTHERN MAIDENHAIR FERN 


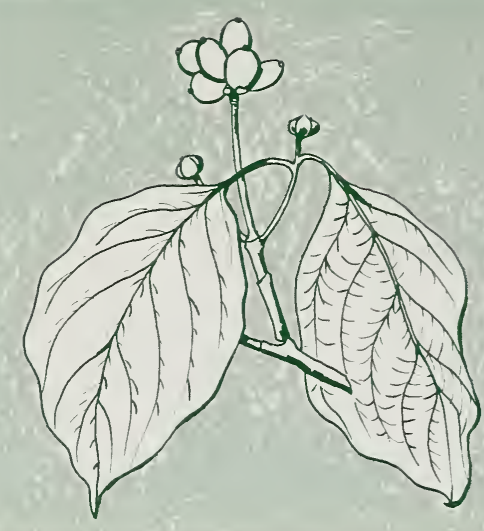

DOGWOOD

21. This is another native oak, the CHESTNUT OAK (Quercus prinus). Its leaves resemble those of the American chestnut. Notice its deeply grooved bark. Just beyond, on the bank to the right, are the sweetfern, juniper, and other plants characteristic of dry locations.

In the open area along the stream near the road are plants that would be found in a moist, sunny meadow, including sensitive fern and marsh fern, wild hyacinth, iris, lilies, swamp nilkweed, and tall meadow rue.

22. The small tree behind this marker and the similar tree to the left are BALD CYPRESS (Taxodium distichum). In swamps in the South this tree grows cypress knees. As these trees grow larger they may develop knees here. Knees are root projections above the soil surface to allow exchange of air between roots and atmosphere.

23. The showy white "flowers" of the FLOWERING DOGWOOD /Cornus florida) are really bracts, or modified leaves. The true flowers are the small greenish cluster in the center.

24. The tree behind the marker is the MOCKERNUT (Carya tomentosa), a hickory very common in the South. Its wood has many uses, including imple. ment handles and baseball bats.

25. The SWEET GUM (Liquidambar stryaciflua) is a common tree on the Coastal plain from Washington, D. C., south. Its star-shaped leaves turn brilliant colors in the fall.

26. The tall fern near the stream is OSTRICH FERN (Matteuccia stru thiopteris) found in damp soil and along streams. Its name comes from the supposed resemblance of its fronds to the shape of an ostrich feather. Notice how the fronds narrow abruptly at the tip. 27. The drooping evergreens on each side of the waterfall are DOGHOBBLE (Leucothoe editorum), native to the southern Appalachians. Like rhododendrons, mountain laurel, and blue berries, this plant is a member of the heath family and does best in acid soil.

28. Though the HAY SCENTED FERN (Dennstaedtia punctilobula) appears delicate, it is a weedy fern that spreads rapidly by underground roots. It is abundant on the hillside farther along the path. 29. Just beyond marker 28 , toward the top of the hill, is a small tree, the AMERICAN HORNBEAM /Carpinus

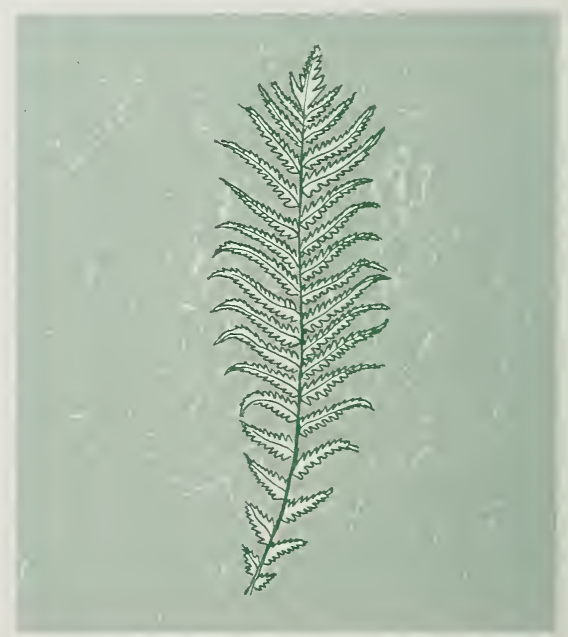

OSTRICHFERN 
caroliniana). The smooth sinewy bark is typical of this tree. It is a common understory tree in moist woods.

30. The plants with the umbrella-like leaves are MAY APPLE (Podophyllum peltatum). The white flowers and greenish fruit appear beneath the leaves. 31. This is the BLADDER NUT (Staphylea trifolia), a shrub or small tree that grows in moist woods. Its drooping clusters of white flowers are followed by bladder-like fruit, which may be seen on the tree in fall or winter.

32. The reddish rock across the stream is a local sandstone sometimes called "bog ironstone." The soil around such a rock will be acid.

33. The low plant growing over the shallow roots of the beech tree is WILD SEDUM or STONECROP (Sedum ternatum). It resembles cultivated varieties of ten used in rock gardens.

34. This is another oak, SPANISH OAK (Quercus falcata). Notice the many kinds of oaks in the valley. More than 50 species grow in North America.

35. This moist area around the spring is a favorable location for many different ferns. Look for the rounded fronds of the maidenhair fern on the moist bank, the woodfern and ladyfern above the spring, and the crested woodfern and royal fern in the low, wettest spots. In early spring you will see the yellow flowers of the marsh marigold along the spring outlet.

36. Across the stream is a wall of limestone rock, built to prevent erosion of the clay and to provide a habitat for ferns and other plants that need a "sweet" or neutral soil. Here are growing such ferns as the bulbletfern and walking fern and the maidenhairfern spleenwort.

37. The evergreen trees around you are the Canadian hemlock (Tsuga canadensis). On the wet slope toward the stream

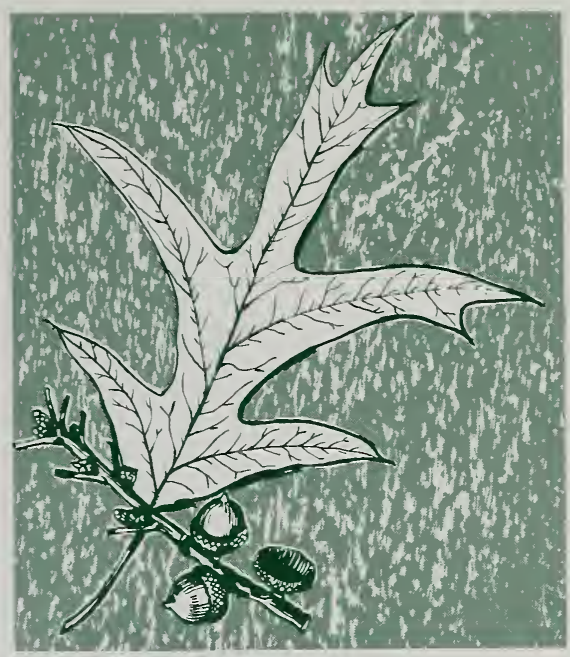

SPANISH OAK

is an association of plants that could be found in an acid, northern bog--plants including goldthread, pitcherplant, Labbrador-tea, and climbingfern.

38. This shaded, moist ravine is a miniature "Fern Valley." Notice the marginal and other wood ferns at the head of the slope. The plant with the straplike leaves on the bank is the hartstongue fern, common in England but rare in this country. Toward the foot of the ravine are the narrow-leaved spleenwort and Goldie fern, which require very moist soil.

At the bend of the path aliead, look out to the open edge or the woods; in summer and fall you will see a group of plants such as you might find in a meadow or along a dry, sunny roadside, including the butterfly-weed, black-eyed susan, and several goldenrods.

39. This is a SCRUB PINE (Pinus virginiana), a short-lived pine common in this area and one of the first trees to invade abandoned fields. While its own seedlings cannot survive in shade, it provides a favorable environment for the seedlings of hardwood trees, which will 


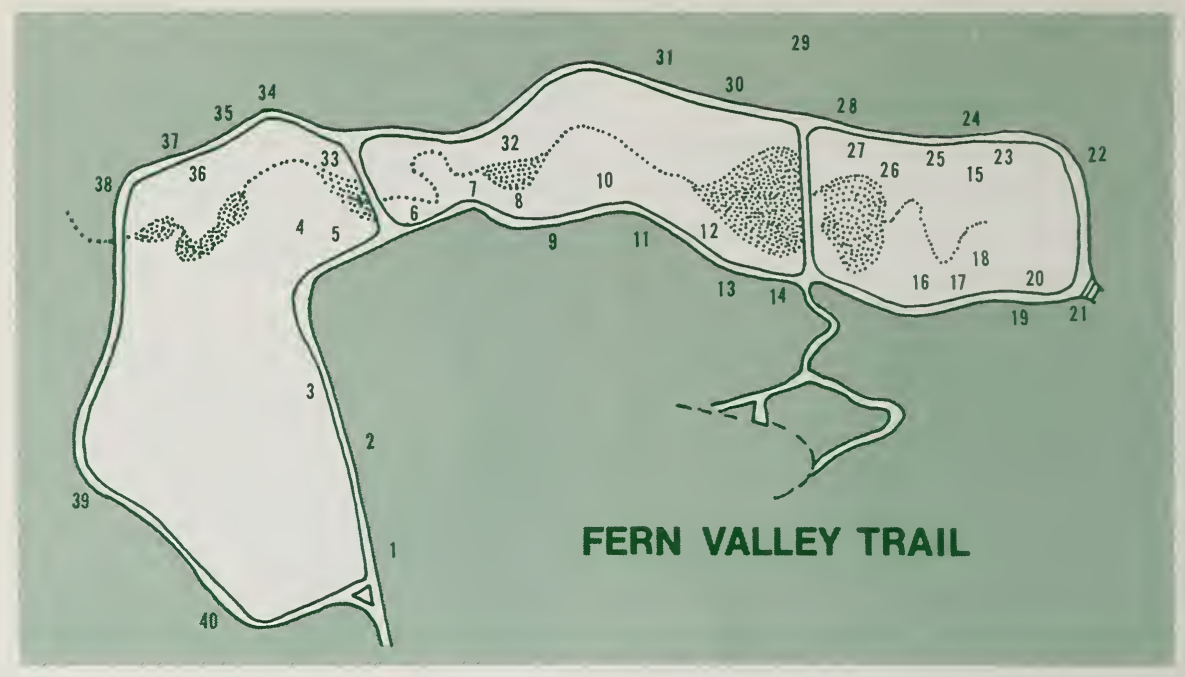

eventually grow tall and take the place of the pines. This sequence of plant (and animal) communities from bare fields to mature forests is known as ecological succession. Farther along the path are smaller WHITE PINES (Pinus strobus), with lighter, softer needles. Both are natives of the northern evergreen-deciduous forest. Notice the plants growing in the acid soil among the pines - the pink ladyslipper, clubmosses. partridgeberry, and wintergreens.

40. The SHAD BUSH or SERVICE BERRY (Amelanchier canadensis) is an early blooming small tree common in northern woods and on mountain slopes. It is called shad bush because it is conspicuous on woods edge and stream beds at the time shad are running. Behind it are the red-berried elder and meadow-sweet.

To learn more about native plants, visit Fern Valley frequently and at different seasons. You will find wildflowers in bloom from early spring to fall, and in summer the ferns at their best. Notice many details about plants-where they grow best, the plants with which they are associated, their growth habit, leaf form. flowers, and fruit. Seeing these things will help you to recognize and remember these plants. 